\title{
Research Paper Economics of pears production in Himachal Pradesh a study of Jubbal and Kotkhai block of district Shimla
}

- Sikander Kumar and Vishal Chauhan

See end of the paper for authors' affiliations

Correspondence to :

Vishal Chauhan

Department of Economics, Himachal Pradesh University, Summer Hill, Shimla (H.P.) India Email: vishal.chauhan333. vc@gmail.com

Paper History :

Received : 09.04.2020;

Revised : 23.07.2020;

Accepted : 25.08 .2020
ABSTRACT : Farm production is the result of the transformation of various resources such as human labour, bullock power, mechanical power, water for irrigation, seeds, manures and fertilizers, insecticides and pesticides and cultivation practices, etc. As these all factor inputs are costly and scarce, the case for their efficient use is self-evident. Moreover, farm resource endowment and the extent of their use on farms has a direct bearing in determining the overall level of crop production. Therefore, it is necessary to study the extent and magnitude of various farm endowments prevailing on farms in different size classes in the study area.The study was conducted at Jubbal and Kotkhai block of district Shimla from where sample of 200 farmers of different holdings were collected to understand the input-output relationship for pears production and was analyized with the Cobb-Douglas production function. From the study we tried to understand the resource efficiency by calculating the elasticity co-efficient of different inputs (labour man-days, land, manures and fertilizers, seeds and others) with regards tooutput and, therefore, determining the economics of scales of fruit. We have found that land, labour, manures and fertilizersinputs are influencing the pears production across all farm size however, small farm size resource efficiency is good as compare to other farm holdings.

KEY WORDS : Economics of scale, Elasticity co-efficient, Input-output, Production, Resource efficiency

How To Cite This Paper: Kumar, Sikander and Chauhan, Vishal (2020). Economics of pears production in Himachal Pradesh a study of Jubbal and Kotkhai block of district Shimla. Internat. Res. J. Agric. Eco. \& Stat., 11 (2) : 248-254, DOI : 10.15740/HAS/IRJAES/11.2/248-254. Copyright@2020:Hind Agri-Horticultural Society. 